\title{
The Effectiveness of Modern Physics Learning Tools Using the PhET Virtual Media Assisted Inquiry Model in Improving Cognitive Learning Outcomes, Science Process Skills, and Scientific Creativity of Prospective Teacher Students
}

\author{
Susilawati ${ }^{12^{*}}$, Aris Doyan ${ }^{1,2^{*}}$, Lalu Mulyadi ${ }^{2}$, Chistine P. Abo ${ }^{3}$, Chester Ian Sotto Pineda ${ }^{4}$ \\ ${ }^{1}$ Physics Education Program, Faculty of Teacher Training and Education, University of Mataram, Indonesia \\ ${ }^{2}$ Master Science Education Program, Postgraduate, University of Mataram, Mataram, Indonesia. \\ ${ }^{3}$ Sultan Kudarat State University, Philippines \\ ${ }^{4}$ Special Science Teacher I, Department of Education Libertad National High School, Philippines
}

DOI: $10.29303 /$ jppipa.v8i1.1304

\section{Article Info}

Received: December 17, 2021

Revised: January 15, 2022

Accepted: January 19, 2022

Published: January 31, 2022

\begin{abstract}
This study aims to test the effectiveness of developing modern physics learning tools using an inquiry model with the help of PhET virtual media in improving cognitive learning outcomes, science process skills, and creativity of prospective teacher students. The development of these learning tools uses a $4 \mathrm{D}$ development research model, namely define, design, develop and disseminate. The sample used in this study were all undergraduate students in one class who took modern physics courses with a total of 20 people. The tests given are in the form of cognitive tests, science processing skills tests, and creativity tests. The improvement in learning outcomes was analyzed using the N-gain test. The results of the $\mathrm{N}$-gain analysis for all aspects indicate that the use of these devices has increased, namely cognitive learning outcomes, science process skills, and student creativity with a high category. These results indicate that the use of physics learning tools modern use of the inquiry model with the help of virtual media PhET is effective for cognitive learning outcomes, science process skills, and scientific creativity of prospective teacher students.
\end{abstract}

Keywords: Cognitive; Inquire model; PhET; Scientific creativity; Science process skill

Citation: Susilawati, S., Doyan, A., Mulyadi, L. ., Abo, C. P., \& Pineda, C. I. S. (2022). The Effectiveness of Modern Physics Learning Tools Using the PhET Virtual Media Assisted Inquiry Model in Improving Cognitive Learning Outcomes, Science Process Skills, and Scientific Creativity of Prospective Teacher Students. Jurnal Penelitian Pendidikan IPA, 8(1), 291-295. https:// doi.org/10.29303/jppipa.v8i1.1304

\section{Introduction}

Modern physics is a branch of science from physics. Modern physics is a branch of physics that deals with physical phenomena from a modern point of view to explain physical phenomena that cannot be explained classically. Modern physics is one of the compulsory courses that students of the physics education study program at the University of Mataram must take. Modern physics learning outcomes are still relatively low. This can be seen in the many students who have to repeat modern physics courses in other semesters. Difficulty in studying modern physics is influenced by its abstract material, making it difficult for students to understand.

Modern physics learning will run smoothly if good planning is carried out following the nature of physics learning which emphasizes science process skills and scientific creativity (Fatwa, et al., 2018), Munthe and Bermawi, 2009). Good quality learning will be achieved if good learning tools are available. Improving the quality of learning for a lecturer is very 
strategic because the lecturer functions as the spearhead of the change from not being able to become capable, from not being able to master to mastering, and from not understanding to understanding (Khasanah, et al., 2019). Besides, student factors, available facilities, tools, and media, as well as environmental factors can also affect the learning process (Kartini, et al., 2019). One of the factors that affect the quality of learning is the use of appropriate learning models. The choice of learning model must be following the material being taught (Wahyudi, et al., 2019).

One of the learning models that can provide opportunities for students to understand the concepts of modern physics is the guided inquiry learning model (Susilawani, et al., 2019). Inquiry learning is designed to invite students directly into the scientific process in a relatively short time. Implementation of the guided inquiry learning model emphasizes the activities of students maximally to train critical thinking skills to improve student learning outcomes (Susilawati, et al., 2019).

In addition to the application of appropriate learning models, another factor that affects the learning process is the use of appropriate learning media. Even more so for modern abstract physics material. The media used can be real media and virtual media (Sugiono, 2014). For modern physics learning, virtual media is needed because the material is focused on physical phenomena that cannot be observed directly. One of the virtual media that is currently available and can be used as a media for learning media for virtual laboratory production from PhET Colorado. PhET has theoretical and experimental simulations that actively involve the user. PhET simulation can display a physics animation that is abstract or cannot be seen by the naked eye such as atoms, electrons, photons, and magnetic fields. Besides being able to build concepts, PhET can also be used to bring up science process skills.

\section{Method}

Modern physics learning tools use an inquiry model with the help of virtual media. PhET is developed using a $4 \mathrm{D}$ model design (define, design, develop and disseminate) (Fraenkel, et al., 2012). The research design used in this study was a one-group pretest-posttest design to obtain data on the effectiveness of learning devices (Doyan, et al., 2020).

The sample used in this study were all prospective teacher undergraduate students in one class who took modern physics courses with a total of 20 people. Before the modern physics learning device was given, all students were given a preliminary test that aims to find out the initial knowledge possessed by students who take modern physics courses. Furthermore, the final test is given to determine the increase in cognitive learning outcomes, science process skills, and scientific creativity. The tests given are in the form of cognitive tests, science processing skills tests, and creativity tests. Quantitative data analysis was used to determine cognitive learning outcomes, science process skills, and creativity of prospective teacher students. The increase in learning outcomes is measured by the $\mathrm{N}$-gain test (Doyan, et al., 2020). The results of the N-gain calculation obtained are matched with the N-Gain. The $\mathrm{N}$-Gain value consists of high ( $\mathrm{N}$-gain $>0.7)$, medium $(0.70>\mathrm{N}$-gain $\geq 0.30)$, and low $(\mathrm{N}$-gain $<0.3)$ categories (Susilawati, 2019).

\section{Result and Discussion}

Analysis of research data in the cognitive domain consisted of the pre-test, post-test, and $\mathrm{N}$-gain scores. The mean score for the pre-test was 44.30 , while the average score for the post-test was 81.05. Based on the pre-test and post-test data, it can be determined the value of the increase in learning outcomes by calculating the $\mathrm{N}$-gain value. The results of the analysis of the $\mathrm{N}$-gain value obtained for each student are shown in Figure 1.

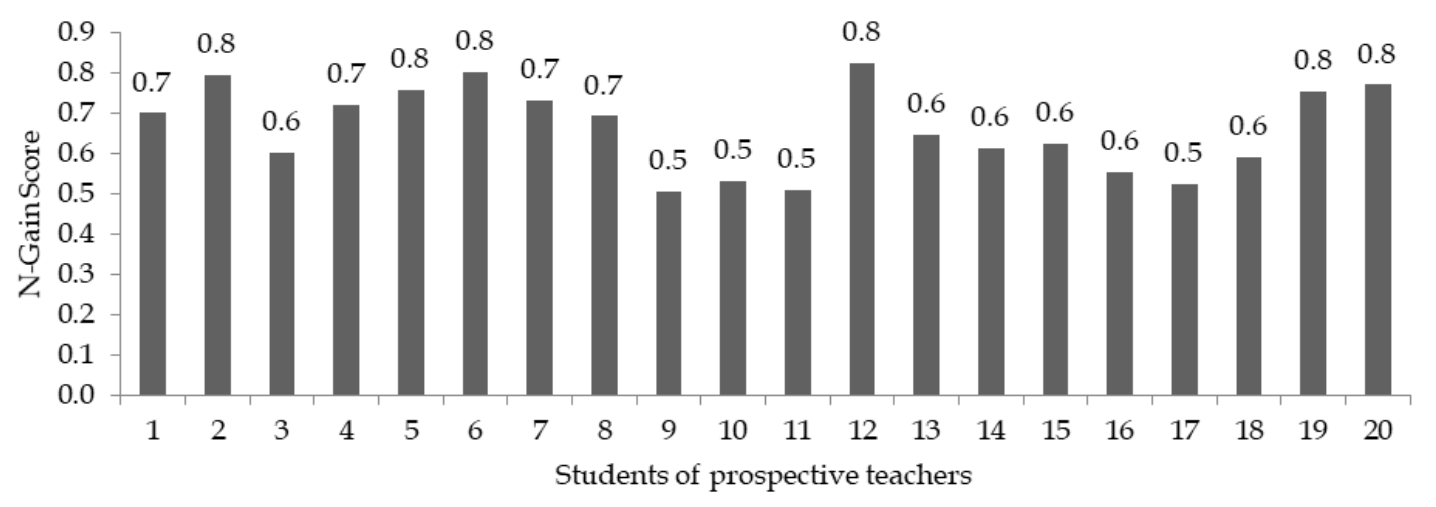

Figure 1. Graph of the N-Gain score of each student of prospective teacher 
Based on Figure 1. it is clear that the N-gain value for each student ranges from 0.5 to 0.8 . This means that the value of improving student learning outcomes by using modern physics learning tools using the inquiry model with the help of virtual media PhET is in the medium to high category. This shows that the use of the inquiry model with virtual media PhET greatly affects the cognitive learning outcomes of prospective teacher students (Nurmayani, et al., 2018; Susilawati, et al., 2019).

Analysis of the next research data is on the aspects of science process skills. Indicators for aspects of science process skills include the ability to observe, propose hypotheses, predict, design experiments to interpret data, communicate, and apply concepts. Descriptive analysis for each aspect is given in the form of the average mastery of each aspect. After that, the average of each aspect mastery is described in the category of the level of mastery of aspects of science process skills. The average percentage of mastery of each component of the science process skills obtained is shown in Figure 2.

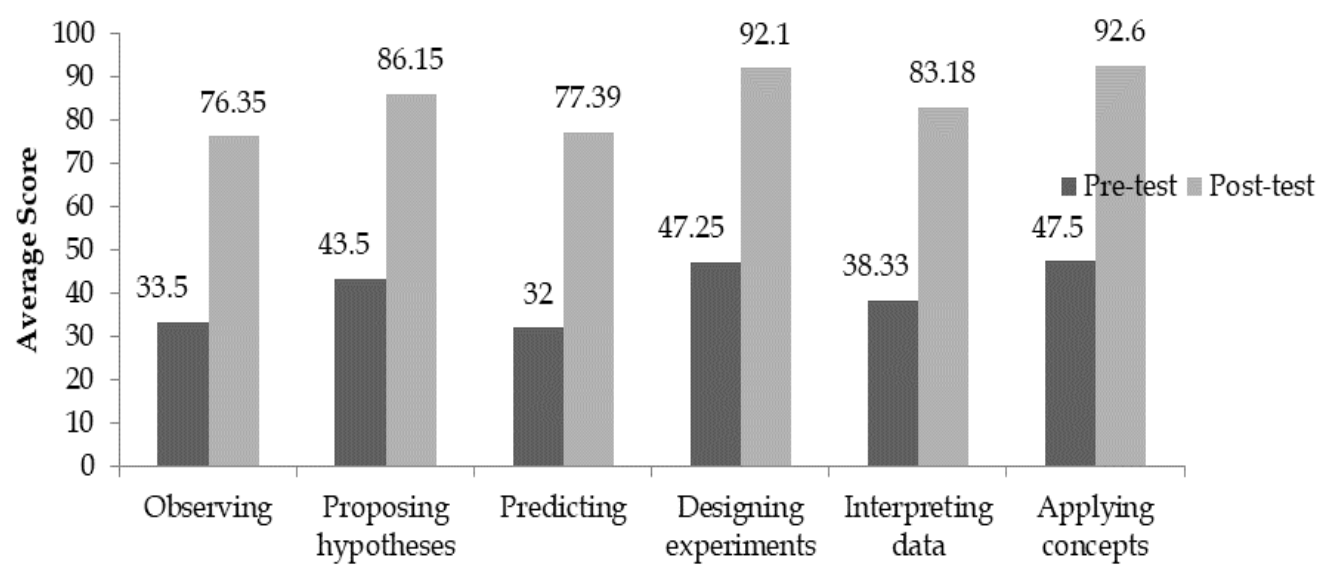

Figure 2. Average mastery of science process skills aspects

Based on Figure 2. it is clear that the pre-test has an average of less than 50 so that it is in the category of "very poor". It is different from the average in the posttest, where the data is categorized as "good" for indicators of observing and predicting, while the "very good" category is for indicators of proposing hypotheses, designing experiments, interpreting data, and applying concepts.

The scores for the pre-test and post-test of science process skills as a whole were 41.35 and 73.50 . The results of the $\mathrm{N}$-gain value analysis were 0.77 with the high category. The high value of improvement shows that there is an effect of using modern physics learning tools using the inquiry model with the help of PhET virtual media on the science skills of prospective teacher students (Asy'ari, et al., 2019; Astutik, et al., 2018). This is because the use of the inquiry model with the help of virtual media PhET helps students practice science process skills such as observing, proposing hypotheses, predicting, designing experiments, interpreting data, and applying concepts. PhET provides experience in conducting abstract experiments with all kinds of possibilities (Doyan, et al., 2014).

Analysis of the next research data is on the aspects of students' scientific creativity. Indicators for the aspect of creativity include fluency, flexibility, and originality. Descriptive analysis for each aspect is given in the form of an average for each aspect. The average for each aspect of students 'scientific creativity obtained is shown in Fig. 3. Based on Fig. 3, it is clear that the average difference between the pre-test and post-test results of the mastery of students' scientific creativity aspects is evident. Fig. 3 shows that the post-test score is higher than the pre-test.

The scores for the pre-test and post-test of student scientific creativity as a whole were 33.31 and 72.41 . The results of the analysis of the $\mathrm{N}$-gain value were 0.76 in the high category. The high value of increase shows that there is an effect of using modern physics learning tools using the inquiry model with the help of PhET virtual media on student scientific creativity (Palupi, et al., 2020). This is because the inquiry model provides opportunities for students to solve problems critically, analytically, and scientifically by using certain steps towards convincing conclusions because it is supported by data or reality so that it can increase students' scientific creativity (Ramlee, et al., 2019; Verawati, et al., 2020) 


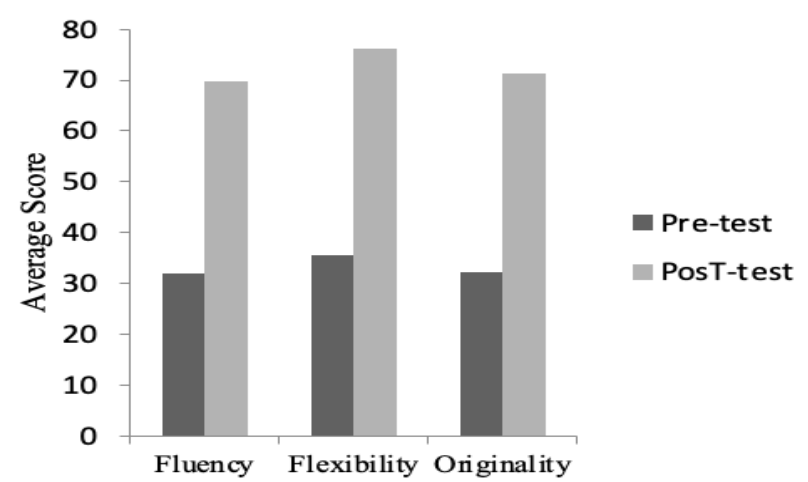

Figure 3. Average mastery in the aspect of scientific creativity

Based on the results of the above research (Figure 3), it can be seen that the use of the inquiry model with the help of PhET virtual media helps improve students' thinking skills. Increased thinking skills of students will have a positive effect on learning outcomes, especially for abstract modern physics material. By using PhET media, students are helped in the problem-solving process. For example, in the photoelectric effect material. By using PhET, students can observe the effect of electric photos directly and try to do experiments to find out the quantities that affect and the relationship of each quantity. This of course will greatly help students to better understand the material.

\section{Conclusion}

Based on the results of the analysis, it can be concluded that modern physics learning tools using the PhET virtual media assisted inquiry model can affect the learning outcomes of prospective teacher students. The use of these tools can improve cognitive learning outcomes, science process skills and scientific creativity of prospective teacher students. These results indicate that the use of modern physics learning tools using an inquiry model with the help of PhET virtual media is effective for cognitive learning outcomes, science process skills and scientific creativity of prospective teacher students.

\section{Acknowledgments}

The writer thanks to the physics education study program, FKIP, Mataram University has facilitated this research. The authors also thank all those who have helped in this research.

\section{References}

Astutik, S., \& Binar, K. (2018). The Practicality and Effectiveness of Collaborative Creativity Learning (CCL) Model by Using PhET Simulation to
Increase Students' Scientific Creativity. International Journal of Instruction, 11, 409-424. https://doi.org/10.12973/iji.2018.11426a.

Asy'ari, M., Fitriani, H., Zubaidah, S., \& Mahanal, S. (2019). The Science Process Skills of Prospective Biology Teachers in Plant Cell Material Based on Gender. International Journal of Emerging Technologies in Learning (IJET), 14, 168-178. https://doi.org/10.3991/ijet.v14i19.11208

Doyan, A., \& Sukmantara, I. (2014). Pengembangan Web Intranet Fisika Untuk Meningkatkan Penguasaan Konsep Dan Kemampuan Pemecahan Masalah Siswa Smk. Jurnal Pendidikan Fisika Indonesia, 10(2), 117-127. doi:https:// doi.org/10.15294/jpfi.v10i2.3447.

Doyan, A., Gunawan, G., Susilawati, Khasanah, B., \& Muliyadi, L. (2020). The effectiveness of quantum phenomenon learning media with think pair share model implementation on understanding concept of students. Journal of Physics: Conference Series, 1521, 22037. https://doi.org/10.1088/17426596/1521/2/022037.

Doyan, A., Susilawati, Kosim, Wardiawan, Z., Hakim, S., Muliyadi, L., \& Hamidi. (2020). The development of physics module oriented generative learning to increase the cognitive learning outcomes and science process skills of the students. Journal of Physics: Conference Series. https://doi.org/10.1088/17426596/1521/2/022059.

Fraenkel, J.R., Wallen, N. E., and Hyun, H. H.. (2012). How to Design and Evaluate Research in Education (8th ed.). New York: McGraw-Hill

Kartini, K., Doyan, A., Kosim, K., Susilawati, S., Khasanah, B. U., Hakim, S., \& Muliyadi, L. (2019). Analysis of Validation Development Learning Model Attainment Concept to Improve Critical Thinking Skills and Student Learning Outcomes. Jurnal Penelitian Pendidikan IPA, 5(2), 185-188. https://doi.org/10.29303/ippipa.v5i2.262

Khasanah, B. U., Doyan, A., Gunawan, G., Susilawati, S., Kartini, K., Hakim, S., \& Muliyadi, L. (2019). Analysis Validation of Learning Media Quantum Phenomenon. Jurnal Penelitian Pendidikan IPA, 5(2), 189-193. https:// doi.org/10.29303/ippipa.v5i2.265.

Nurmayani, L., Doyan, A., \& verawati, N. N. S. P. (2018). Pengaruh Model Pembelajaran Inkuiri Terbimbing Terhadap Hasil Belajar Fisika Peserta Didik. Jurnal Penelitian Pendidikan IPA, 4(2). https://doi.org/10.29303/jppipa.v4i2.113.

Munthe, \& Bermawi. (2009). Desain Pembelajaran. Yogyakarta: Publisher Pustaka Insan Madani.

Palupi, B., Subiyantoro, S., Triyanto, T., \& Rukayah, R. (2020). Creative-Thinking Skills in Explanatory Writing Skills Viewed from Learning Behaviour: A 
Mixed Method Case Study. International Journal of Emerging Technologies in Learning (IJET), 15, 200. https://doi.org/10.3991/ijet.v15i01.11487.

Ramlee, N., Rosli, M. S., \& Saleh, N. S. (2019). Mathematical HOTS Cultivation via Online Learning Environment and 5E Inquiry Model: Cognitive Impact and the Learning Activities. International Journal of Emerging Technologies in Learning (iJET), 14(24), pp. 140-151. https://doi.org/10.3991/ijet.v14i24.12071.

Sugiyono. (2014). Metode Penelitian Pendidikan Pendekatan Kuantitatif, Kualitatif, dan RED. Bandung: Alfabeta.

Susilawati, S., Doyan, A., Harjono, A., \& Kosim, K. (2019). Penerapan Model Pembelajaran Inkuiri Berbasis Media Virtual Program Java Pada Guru Fisika Dan Siswa SMA. Jurnal Pengabdian Masyarakat Sains Indonesia, 1. https://doi.org/10.29303/jpmsi.v1i1.3.

Susilawani, S., Doyan, A., \& Ayub, S. (2019). Perbedaan Keterampilan Generik Sains Antara Model Pembelajaran Berbasis Masalah Dengan Inkuiri Terbimbing Ditinjau Dari Kemampuan Berpikir Kritis Siswa SMA. Jurnal Pendidikan Fisika dan Teknologi, 5(1), 16-24. doi:http://dx.doi.org/10.29303/jpft.v5i1.887.

Fatwa, M., Harjono, A., \& Jamaluddin, J. (2018). Pengaruh Model Pembelajaran Inkuiri Terbimbing Terhadap Keterampilan Proses Dan Penguasaan Konsep Sains Ditinjau Dari Pengetahuan Awal Peserta Didik. Jurnal Pendidikan Fisika dan Teknologi, 4(1), 121-130. doi:http://dx.doi.org/10.29303/jpft.v4i1.572

SusilawatiS., DoyanA., ArtayasaP., SoepriantoH., HarjonoA., \& KartiniK. (2020). Effectiveness of Scientific Learning Guided Inquiry Devices Based on Real Media to Improve Understand Concept and Skills Process of Science Students. International Conference on Elementary Education, 2(1), 517-524. Retrieved from http://proceedings.upi.edu/index.php/icee/articl e/view/657.

Verawati, N. N. S. P., Hikmawati, H., \& Prayogi, S. (2020). The Effectiveness of Inquiry Learning Models Intervened by Reflective Processes to Promote Critical Thinking Ability in Terms of Cognitive Style. International Journal of Emerging Technologies in Learning (iJET), 15(16), 212-220. https://doi.org/10.3991/ijet.v15i16.14687

Wahyudi, W., Verawati, N. N. S. P., Ayub, S., \& Prayogi, S. (2019). The Effect of Scientific Creativity in Inquiry Learning to Promote Critical Thinking Ability of Prospective Teachers. International Journal of Emerging Technologies in Learning (iJET), 14(14), 122-131. https://doi.org/10.3991/ijet.v14i14.9532. 